\title{
FORMULATION AND DEVELOPMENT OF TOPICAL ANTI ACNE FORMULATION OF SPIRULINA EXTRACT
}

\author{
BADDURI NIHAL, N. VISHAL GUPTA, D. V. GOWDA*, MANOHAR M.
}

Department of Pharmaceutics, JSS College of Pharmacy, Sri Shivarathreeshwara Nagara, Mysuru, JSS Academy of Higher Education and Research, JSS Medical Institutions Campus, Sri Shivarathreeshwara Nagara, Mysuru 570015, Karnataka, India Email: dvgowda@jssuni.edu.in

Received: 29 Mar 2018, Revised and Accepted: 04 Oct 2018

\section{ABSTRACT}

Objective: The objective of this research was to formulate and evaluate anti-acne ointment of C-phycocyanin(C-PC) extracted from spirulina.

Methods: C-PC was successfully extracted from spirulina by using sonication and cold-maceration process and further purified by dialysis method. By employing disc diffusion and agar dilution method, antimicrobial activity and minimum inhibitory concentration(MIC) of C-PC as determined against Propionibacterium acne (P. acne) and Staphylococcus epidermidis(S. epidermidis). Further, the two different formulations were prepared by using water soluble and oleaginous bases, and the formulations were characterized for particle size, viscosity, pH, consistency, drug diffusion, antimicrobial activity, and antioxidant effect and stability studies.

Results: C-PC showed MIC value of $1.5 \pm 0.1 \mathrm{mg} / \mathrm{ml}$ and $1.8 \pm 0.2 \mathrm{mg} / \mathrm{ml}$ against $P$. acne and S. epidermidis respectively. The developed formulation had a globule diameter of $5.44 \mathrm{~mm}$, $\mathrm{pH}$ of $6.8 \pm 0.09$, the viscosity of $175 \pm 0.2 \mathrm{cps}$, spreadability of an $8.6 \pm 0.12 \mathrm{~g}$. cm/sec and had good consistency. Both formulations were found stable among which, formulation B(FB) had maximum drug content of $95 \pm 0.6 \%$ and drug release was up to $92 \pm 0.8 \%$.

Conclusion: The prepared topical C-PC ointment can be successfully employed in the treatment of acneagainstP. acne and S. epidermidis.

Keywords: Acne vulgaris, Antibacterial activity, MIC, Spirulina, Ointment, In vitro activity

(C) 2018 The Authors. Published by Innovare Academic Sciences Pvt Ltd. This is an open access article under the CC BY license (http://creativecommons.org/licenses/by/4.0/] DOI: http://dx.doi.org/10.22159/ijap.2018v10i6.26334

\section{INTRODUCTION}

Acne is a long-term skin disease that arises when hair sacs are blocked with departed skin cells [1]. It is categorized by spots, blackheads, whiteheads, redness, inflammations or oily skin [2,4]. It can be of the inflammatory and non-inflammatory type of acne. Non-inflammatory includes blackheads, whiteheads while inflammatory includes pimples that are red and swollen. Skin areas with comparatively higher in oil glands such as the face, superior part of the upper body, and posterior majorly affected [5]. The subsequent presence may lead to nervousness, reduced confidence and downheartedness $[6,7]$. Genetics and increased sex hormones during adolescence in both the genders are the primary causes of acne in $78 \%$ of cases $[3,10]$. However, the role of food and smoking is still unclear $[8,9]$. P. acne and S. epidermidisare the two major gram-+ve bacterial species responsible for acne vulgaris. The former one is an anaerobic, rod-shaped bacteria which lives at the base of the hair follicle breaks down sebum to consume as food, as bacteria increases, it causes inflammation which results in an immune response. Whereas the later induces acne together with other skin bacteria.

Spirulina is a microscopic filamentous marine cyanobacterium of genus spirulina, especially Arthrospiraplatensis that is used as a dietary supplement which consists of $70 \%$ protein by weight [11]. Of these proteins, the phycobiliproteins (antenna-like proteins involved in light harvesting) named allophycocyanin, $\mathrm{C}-\mathrm{PC}$ and phycoerythrin. C-PC is a holoprotein and also known as phycobiliproteins [12, 14]. It is responsible for most of the natural benefits being delivered by spirulina. C-PC and $\beta$-carotene that have potent antioxidant, antimicrobial and anti-inflammatory activities, exerts strong free radical scavenging activity, inhibits pro-inflammatory cytokine formation, such as TNF $\alpha$, suppresses cyclooxygenase-2 (COX-2) expression and decreases prostaglandin E2 production [13]. Due to increased instances of resistance of acne-inducing bacteria towards the synthetic drugs, the alternate system of medicine for the treatment of acne have been investigated and adopted. Among the alternate systems of medicine, the topical therapeutic agents are more convenient for application. Topical acne treatment is occupying the upper position as they are safe, dilute, patient familiar, economical, easily available and multifunctional. Hence spirulina is natural and possessing both anti-inflammatory and antioxidant properties, the present study aims to explore its application in the treatment of acne and also evaluate the antimicrobial property of the spirulina containing C-PC against acne-causing species.

\section{MATERIALS AND METHODS}

Spirulina was procured from Genius natural herbs Pvt. Ltd. Coimbatore, India. Paraffin hard, cetostearyl alcohol and liquid paraffin are obtained from Loba Chemie. Pvt. Ltd, Mumbai. Wool fat and white soft paraffin were procured from Rajesh chemi. Pvt. Ltd, Mumbai. PEG400, PEG4000, ammonium sulfate and stearyl alcohol were procured from Merckspecialties. pvt, Ltd. Mumbai. The sodium dodecyl sulfate-polyacrylamide gel electrophoresis (SDS-PAGE) and the molecular indicator was procured from genei Pvt Ltd Bangalore. $P$. acne and S. epidermidis were procured from NCL, Pune.

\section{Extraction of protein}

Cold maceration and sonication are two methods used for isolation of CPC. In cold maceration process $1: 25(\mathrm{w} / \mathrm{v})$ spirulina dry powder: water at $40{ }^{\circ} \mathrm{C}$ for $24 \mathrm{~h}$. In the sonication process, $1: 25(\mathrm{w} / \mathrm{v})$ of Spirulina dry powder in $\mathrm{H}_{2} \mathrm{O}$ was sonicated at $40 \mathrm{kHz}$ for $45 \mathrm{~min}$. The semi-liquid mixture obtained was subjected for centrifugation at $1000 \mathrm{rpm}$ for 20 min at $4{ }^{\circ} \mathrm{C}$. The precipitate (ppt) was discarded and the supernatant layer was collected. The $\mathrm{pH}$ was set to $\mathrm{pH} 7.0$ for subsequent stages [17].

\section{Purification}

\section{(NH4) ${ }_{2} \mathrm{SO}_{4}$ precipitation}

To attain $50 \%$ saturation, $\left(\mathrm{NH}_{4}\right) 2 \mathrm{SO} 4$ solution was added to $100 \mathrm{ml}$ extract with non-stop stirring. The solution was thenkeptside for 120 min. Later was centrifuged at $1200 \mathrm{rpm}$ for $30 \mathrm{~min}$. The blue ppt found was liquefied in $0.005 \mathrm{M}$ Sodium-phosphate buffer (pH-7.0)[17]. The concentration was calculated by Boussiba and Richmond method [16] and purity by Bennett and Bogorad method [15].

\section{Dialysis and gel filtration}

The solution was dialyzed overnight at $4{ }^{\circ} \mathrm{C}$ counter to one liter of $0.005 \mathrm{M}$ sodium phosphate buffer ( $\mathrm{pH}-7.0)$. The obtained solution 
was filtered by fleeting over a Sephadex G-25 column $(12 \times 2 \mathrm{~cm})$. Elements were collected at a flow rate of $0.5 \mathrm{ml} / \mathrm{min}$ [17].

\section{Electrophoresis in polyacrylamide gel}

In a vertical chamber using $12 \%$ SDSPAGE [19]. The sample obtained after dialysis was subjected to electrophoresis and gel filtration. Molecular indicators were a protein marker wide range, (Myosin $205 \mathrm{kDa}$, Phosphorylase B 97.4 kDa Bovine serum albumin $66 \mathrm{kDa}$, Ovalbumin $43 \mathrm{kDa}$, Carbonic anhydrase $29 \mathrm{kDa}$, Soybean trypsin inhibitor $20.1 \mathrm{kDa}$, Lysozyme $14.3 \mathrm{kDa}$, Aprotinin $6.5 \mathrm{kDa}$, Insulin $3.5 \mathrm{kDa}$.) The gel was marked by $0.1 \%$ Coomassie Brilliant G250 solution after electrophoresis [18]

\section{Antioxidant activity of C-phycocyanin}

Determination of the activity of C-PC-from spirulina sample was done by electron spin resonance (ESR) spectroscopy [20]. The ESR spectrometer Bruker $300 \mathrm{E}$ registers all ESR spectra. The antioxidant activity of C-PC was found in the concentration range of $0.05-0.3 \mathrm{mg} \mathrm{ml}-1$. 2,2-diphenyl-1-picrylhydrazyl (DPPH) artificial constant was taken as standard. The enactment of ESR quantities was held in the following conditions: field modulation $100 \mathrm{kHz}$, modulation amplitude $0.256 \mathrm{G}$, receiver gain $2 \times 10^{4}$, the time constant $40.96 \mathrm{~m}$, conversion time $327.68 \mathrm{~m}$, centre field $3440.00 \mathrm{G}$, sweep width $100.00 \mathrm{G}$, x-band frequency $9.45 \mathrm{GHz}$, power $7.96 \mathrm{~mW}$, at $25{ }^{\circ} \mathrm{C}$. The antioxidant activity of C-PC was defined as: $\mathrm{AA}_{\mathrm{DPPH}}=100 \times\left(h_{o}-h_{x}\right) / h_{o}$ [\%], In the ESR spectrum of DPPH radicals of the blank and probe, $h_{o}$ and $h_{x}$ are the height of the $2^{\text {nd }}$ peak respectively.

\section{Preparation of the ointment}

Two formulations FA and FB consisting of oileogenous base and water base respectively were prepared (table 1 and 2).

Table 1: Formulation chart of oleaginous base

\begin{tabular}{ll}
\hline Ingredients & Quantity in \% \\
\hline Paraffin hard & 5 \\
Wool fat & 10 \\
Cetostearyl alcohol & 10 \\
White soft paraffin & 50 \\
Liquid paraffin & 15 \\
Extract(C-PC) & 10 \\
\hline
\end{tabular}

Ointment base was prepared by adding cetostearylalcohol and wool fat in melted hard paraffin. Finally, white soft paraffin was added and mixed thoroughly on heating mantle and kept aside. Other ingredients were weighed accordingly and added to the above mixture (step 1).
A measured quantity of extract(C-PC) and liquid paraffin were poured into a motor pestle and stirred in one direction by adding the required quantity of the ointment base until a homogenous product is obtained. The prepared formulations were stored in ointment tubes for further studies.

Table 2: Formulation chart of the water-soluble base

\begin{tabular}{lc}
\hline Ingredients & Quantity in \% \\
\hline PEG400 & 12 \\
PEG4000 & 18 \\
Stearyl alcohol & 28 \\
Extract & 10 \\
Glycerine & 17 \\
Water & q.s \\
\hline
\end{tabular}

The required quantity of the ingredients and extract were weighed and stirred thoroughly at a low temperature until the uniform base is formed. The volume was made up to the required quantity with water and stored in an ointment tube at room temperature until further studies were carried out.

\section{Evaluation test}

\section{Physical parameters and identification test}

The preparation was mixed with water, and the odour was observed. By placing the formulation against white background colour was observed. By applying the formulation on the hand, greasiness was observed and identification was done visually by placing it in white background.

\section{Uniformity of weight \%}

Randomly filled 20tubes were weighed. The tubes were emptied, washed with alcohol and dried. The weight of the empty tubes was measured using a digital weighing balance (Shimadzu digital weighing balance model no; BL220H). The difference between the weights was calculated as the net weight of the ointment tube. The average net weight of 20 tubes was noted [21].

\section{Globule diameter}

With the help of projection microscope, SIPCON SP, 585. The average diameter was calculated.

\section{pH}

Digital pH meter ELICO LI120 (type 003) was employed. About 10g of the formulation was diluted and exposed to $\mathrm{pH}$ measurement.

\section{Loss on drying}

The ointment was taken in a dry Petri dish on a water bath and dried for $100^{\circ} \mathrm{C}$. Loss on drying was determined [21].

$$
\text { percentage loss on drying }=\frac{(\text { Weight }- \text { Molecularweight })}{\text { Weight }} \times 100
$$

\section{Spreadability}

Between 2 glass slides $1 \mathrm{~g}$ of, the ointment was placed and 100g of weight $(\mathrm{m})$ was placed above the plates. The extra was scrapped off after removing the weight. Lesser the time is taken $(\mathrm{t})$ is taken separation of the two slides, the better is the spreadability(S) [22].

$$
S=m \times(l \div t)
$$

\section{Consistency or hardness of ointment}

Three samples were melted and filled into containers without air bubbles and sheared for $5 \mathrm{~min}$ then stored at $25 \pm 0.5^{\circ} \mathrm{C}$ for $24 \mathrm{~h}$. samples were tested using Penetrometer by adjusting the temperature at $25+0.5^{\circ} \mathrm{C}$ and position was adjusted such that its tip just touches the surface of the sample and was released for $5 \mathrm{sec}$ and penetration depth was measured and repeated with other samples [23]. 


\section{Test of the rate of penetration}

The rate of penetration can be predictable with the help of flowthrough diffusion cell. Animal skin of certain known area should be removed and knotted to the receptacle existing in a flow-through diffusion cell and placed in a liquid bath. A known amount of the formulation is smeared on the skin, and the amount of drug penetrated into the fluid is measured by collecting aliquots at regular intervals and measured by using a spectrophotometer [24].

\section{Test of content uniformity}

The gross weight of 10 formulation tubes was measured. The outcomes obtained should tie each other and with the considered amount.

\section{Viscosity of ointment}

The sample was taken in a dry $250 \mathrm{ml}$ beaker, by using spindle nos. 1 to 4 . OF CAP-2000 Brookfield viscometer DV-2 IrPRO (model no; LR99102) viscosity was determined [25].

\section{Microbiological studies}

The antibacterial action of both the FA and FB consisting C-PC against $P$. acne and $S$. epidermidis were estimated by disc diffusion method and the zone of inhibition was measured with zone reader. By using an agar dilution method, MIC was measured. Nutrient agar media was used at $37^{\circ} \mathrm{C}+2^{\circ} \mathrm{C}$ for $2 \mathrm{~d}[26]$.

\section{Diffusion study}

$3 \mathrm{gm}$ of the formulation was placed in the donor section of the modifiedkiescarychein diffusion cell, Electro lab diffusion cell (model no; EDC-07). The receptor section containing $22 \mathrm{ml}$ of phosphate buffer $\mathrm{pH} 7.4$ was in contact with the complete surface of the cellophane membrane. And magnetic stirrer was continuously stirred at $100 \mathrm{rpm}$ at temperature $37 \pm 0.5^{\circ} \mathrm{C} .3 .14 \mathrm{~cm}^{2}$ is the surface area of-of accessible for diffusion. The experiment was carried out by maintaining the sink condition for $5 \mathrm{~h}$, and the sampling interval was $30 \mathrm{~min}$. The content of C-PC was determined.

\section{Stability studies}

Ointment tube were stored at altered temperature condition viz. 25 ${ }^{\circ} \mathrm{C} \pm 2{ }^{\circ} \mathrm{C} / 60 \% \mathrm{RH} \pm 5 \% \mathrm{RH}, 30{ }^{\circ} \mathrm{C}+2{ }^{\circ} \mathrm{C} / 65 \% \mathrm{RH}+5 \% \mathrm{RH}, 40{ }^{\circ} \mathrm{C}+2$ ${ }^{\circ} \mathrm{C} / 75 \% \mathrm{RH}+5 \% \mathrm{RH}$ over 180 days in a thermal humidity chamber, thermolabs, Mumbai and studied for various parameters of the formulations [27].

\section{RESULTS AND DISCUSSION}

Table 3: Identification of ingredients in both FA and FB

\begin{tabular}{lll}
\hline S. No. & Identification & Specification \\
\hline 1 & Hard Paraffin & White Colour \\
2 & Wool Fat & Light Yellow \\
3 & Cetostearyl Alcohol & Color Less \\
4 & White Soft Paraffin & White Color \\
5 & Peg 400 & Color Less \\
6 & Peg 4000 & Color Less \\
7 & Extract & Intense Blue \\
\hline
\end{tabular}

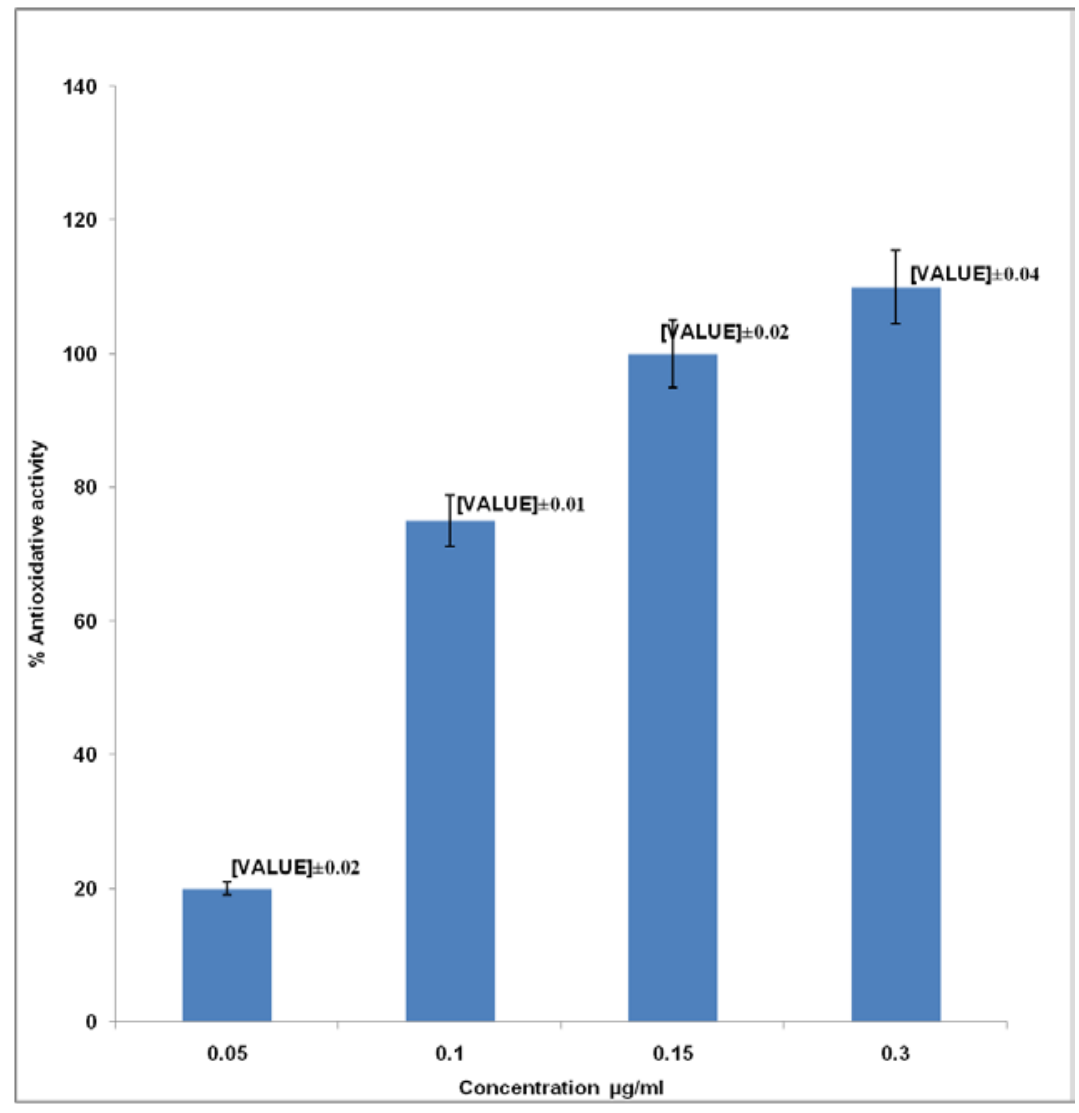

Fig. 1: Antioxidant activity of C-PC $(n=3$, mean \pm SD $)$ 
Table 4: Estimation of various parameters for anti-acne formulation

\begin{tabular}{lll}
\hline Evaluation parameters & FA & FB \\
\hline Explanation & Colour-intense blue & Colour-intense blue \\
& Odour-waxy & Odour-odourless \\
Uniformity of weight & Obey with standard & Obey with standard \\
Globule diameter & $5.29 \mathrm{~mm}$ & $5.44 \mathrm{~mm}$ \\
$\mathrm{pH}$ & $6.1 \pm 0.06$ & $6.8 \pm 0.09$ \\
Loss on drying & $35 \% \mathrm{w} / \mathrm{w}$ & $47 \% \mathrm{w} / \mathrm{w}$ \\
Consistency & Good & Good \\
Viscosity & $198 \pm 0.4 \mathrm{cps}$ & $175 \pm 0.2 \mathrm{cps}$ \\
Spreadability & $8.1 \pm 0.11 \mathrm{g.cm} / \mathrm{sec}$ & $8.6 \pm 0.12 \mathrm{~g} . \mathrm{cm} / \mathrm{sec}$ \\
\hline
\end{tabular}

${ }^{*} \mathrm{n}=3$, mean $\pm \mathrm{SD}$, The consistency of FB was superior to FA. The FA was found to be more viscous $(198 \pm 0.4 \mathrm{cps})$ than FB $(175 \pm 0.2 \mathrm{cps})$. Thus the FB has better spreadability characters $(8.6 \pm 0.12 \mathrm{~g} . \mathrm{cm} / \mathrm{sec})$ than FA $(8.1 \pm 0.11 \mathrm{~g} . \mathrm{cm} . / \mathrm{sec})$.

\section{Antioxidative activity}

C-PC showed $100 \%$ action at the concentration of $0.15 \mathrm{mg}$ $\mathrm{ml}^{-1}$. Spirulina has the action which is analogous to that of Limnothrix. The $\left(\mathrm{EC}_{50}\right)$ value of $\mathrm{C}$-PC was about $0.08 \mathrm{mg}$ $\mathrm{ml}^{-1}$ which is slightly greater, but equivalent to the activity of rutin at an EC50 value of $0.055 \mathrm{mg} \mathrm{ml}^{-1}$ fig. 1 .
Antioxidative activity of C-PC. The bars designate the standard error of 3 dimensions.

From the outcomes, it was found that FB diffusing $0.7 \mathrm{~cm}$ length after $1 \mathrm{hr}$ whereas FA diffuses $0.5 \mathrm{~cm}$ after $1 \mathrm{hr}$ and In vitro drug diffusion for FB was found to be $92 \%$ after $5^{\text {th }} \mathrm{hr}$ and for FA it is $88 \%$. The results are shown in fig. 2 .

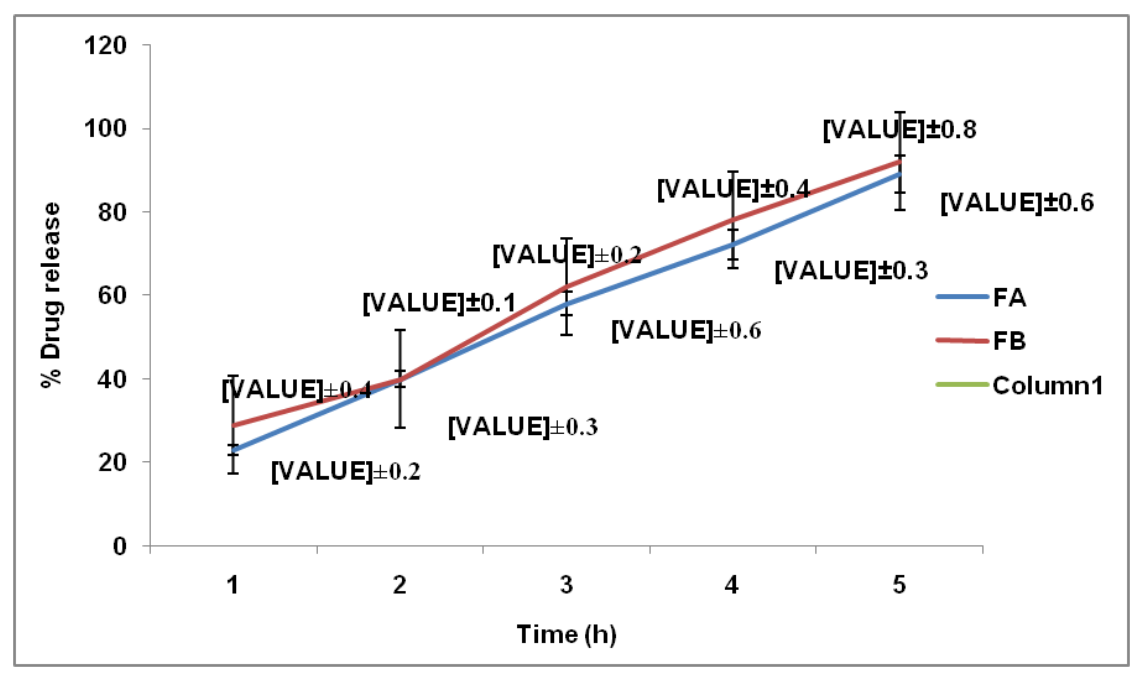

Fig. 2: Diffusion study of formulation $A$ and $B(n=3$, mean \pm SD)

The antimicrobial activity of anti-acne ointment in FA and FB were determined. The zones of inhibition of P. acne and S. epidermidis are described in table 5. Comparatively, FB was found to be superior to FA.

Table 5: Antimicrobial action of anti-acne ointment

\begin{tabular}{llll}
\hline The diameter of zone of inhibition $(\mathrm{mm})^{*}$ & & MIC \\
\hline Formulation & P. acne & S. epidermidis & P. acne \\
\hline A & $23.4 \pm 1.0$ & $21.3 \pm 1.4$ & $1.6 \pm 0.4 \mathrm{mg} / \mathrm{ml}$ \\
B & $26.1 \pm 1.2$ & $24.6 \pm 1.6$ & $1.5 \pm 0.1 \mathrm{mg} / \mathrm{ml}$ \\
\hline
\end{tabular}

${ }^{*} \mathrm{n}=3$, mean $\pm \mathrm{SD}$

Table 6: Stability parameters

\begin{tabular}{|c|c|c|c|c|c|c|}
\hline Parameters (after 3rd week) & FA & & & FB & & \\
\hline Temp & $25^{\circ} \mathrm{C}$ & $30^{\circ} \mathrm{C}$ & $40^{\circ} \mathrm{C}$ & $25^{\circ} \mathrm{C}$ & $30^{\circ} \mathrm{C}$ & $40^{\circ} \mathrm{C}$ \\
\hline $\mathrm{pH}^{*}$ & $6.6 \pm .01$ & $6.6 \pm .02$ & $6.4 \pm .01$ & $6.8 \pm .04$ & $7.1 \pm .03$ & $7.3 \pm .06$ \\
\hline Spreadability $(\mathrm{g} / \mathrm{sec})^{*}$ & $38.6 \pm .2$ & $36.8 \pm .3$ & $42 . \pm .2$ & $44 . \pm .8$ & $42.6 \pm .5$ & $42 . \pm .9$ \\
\hline Consistency & 165 & 163 & 161 & 203 & 202 & 203 \\
\hline Globule diameter & 4.13 & 5.11 & 5.14 & 5.26 & 5.34 & 5.24 \\
\hline
\end{tabular}

$* \mathrm{n}=3$, mean $\pm \mathrm{SD}$, from the above outcomes, it is evidently manifest that there were no fluctuations in the evaluation parameters of both the formulations. Comparatively, FB was found to be further acceptable than FA. 


\section{DISCUSSION}

Antibiotics like tetracycline, salicylic acid etc. show resistance and side-effects, C-PC being natural would be comparatively safe for treating acne. Studies have stated that the aqueous coriander extract had MIC values of $1.7 \mathrm{mg} / \mathrm{ml}$ and $2.1 \mathrm{mg} / \mathrm{ml}$, zone of inhibition of $21.5 \pm 1.4 \mathrm{~mm}$ and $20.6 \pm 1.09 \mathrm{~mm}$ against P. acne and $\mathrm{S}$. epidermidis respectively. Whereas in our present study, the aqueous extract of spirulina has MIC values of $1.5 \pm 0.1 \mathrm{mg} / \mathrm{ml}$ and $1.8 \pm 0.2 \mathrm{mg} / \mathrm{ml}$, the zone of inhibition of $26.1 \pm 1.2 \mathrm{~mm}$ and $24.6 \pm 1.6 \mathrm{~mm}$ respectively. The results indicate that aqueous spirulina extract has better antimicrobial property than aqueous coriander extract [22]

\section{CONCLUSION}

Based on the study results, it is concluded that the spirulina extract possesses anti-acne property. And formulation comprising watersoluble base was superior to the oleaginous base, due to the complete solubility of the extract in water.

\section{ACKNOWLEDGMENT}

The authors are grateful to the JSS College of Pharmacy, Mysore, India, for giving permission to carry out their research work.

\section{AUTHORS CONTRIBUTIONS}

All the author have contributed equally

\section{CONFLICT OF INTERESTS}

The authors declare that there is no conflict of interests regarding the publication of this paper

\section{REFERENCES}

1. AslamI, Fleischer A, Feldman S. Emerging drugs for the treatment of acne. Expert Opin Emerging Drugs 2015;20:91-101.

2. Vary Jr JC. Selected disorders of skin appenages-acne, alopecia, hyperhidrosis. Med Clin North Am 2016;99:1195-211.

3. Bhate K, Williams HC. Epidemiology of acne vulgaris. Br J Dermatol 2013;168:474-85.

4. Peck GL, Olsen TG, Yoder FW, Strauss JS, Downing DT, Pandya $\mathrm{M}$, et al. Prolonged remissions of cystic and conglobate acne with 13-cis-retinoic acid. N Engl J Med 1979;300:329-33.

5. Sri Agung FK, Marline A, Bobby EV. Formulation and evaluation of anti-acne gel containing citrus aurantifolia fruit juice using carbopol as a gelling agent. Int J Appl Pharm 2018;10:147-52.

6. Barnes LE, Levender MM, Fleischer AB, Feldman SR. Quality of life measures for acne patients. Dermatol Clin 2012; 30:293-300.

7. Goodman G. Acne and acne scarring-the case for active and early intervention. Austfam Physician 2006;35:503-4.

8. Knutsen-Larson S, Dawson AL, Dunnick CA, Dellavalle RP. Acne vulgaris: pathogenesis, treatment, and needs assessment. Dermatol Clin 2012;30:99-106.

9. Schnopp C, Mempel M. Acne vulgaris in children and adolescents. Minerva pediatr 2011;63:293-304.

10. James WD. Acne. N Engl J Med 2005;352:1463-72.
11. Campanella L, Russo MV, Avino P. Free and total amino acid composition in blue-green algae. Ann Chim 2002;92:343-52.

12. Grossman AR, Schaefer MR, Chiang GG, Collier JL. The phycobilisome, a light-harvesting complex responsive to environmental conditions. Microbiolrev 1993;57:725-49.

13. Jaouen P, Lepine B, Rossignol N, Royer R, Quemeneur F. Clarification and concentration with membrane technology of a phycocyanin solution extracted from spirulina platensis. Biotechnol Technol 1999;13:877-81.

14. McCarty MF, Barroso-Aranda J, Contreras F. Oral phycocyanobilin may diminish the pathogenicity of activated brain microglia in neurodegenerative disorders. Med hypotheses 2010;74:601-5.

15. Bennett A, Bogorad L. Complementary chromatic adaptation in a filamentous blue-green alga. J Cell Boil 1973;58:419-35.

16. Boussiba $\mathrm{S}$, Richmond $\mathrm{AE}$. Isolation and characterization of phycocyanin from the blue-green alga spirulina plantensis. Arch Microbiol 1979;120:155-9.

17. Silva LA, Kuhn KR, Moraes CC, Burkert CAV, Kalil SJ. Experimental design as a tool for optimization of Cphycocyanin purification by precipitation from spirulina platensis. J Braz Chem Soc 2009;20:5-12.

18. Liao X, Zhang B, Wang X, Yan H, Zhang X. Purification of Cphycocyanin from spirulina platensis by single-step ionexchange chromatography. Chromatographia 2012;73:291-6.

19. Laemmli UK. Cleavage of structural proteins during the assembly of the head of bacteriophage T4. Nature 1970;227:680.

20. Canadanovic-Brunet JM, Cetkovic GS, Djilas SM, Tumbas VT Savatovic SS, Mandic AI, et al. Radical scavenging and antimicrobial activity of horsetail (Equisetum arvense L.) extracts. Int J Food Sci Technol 2009;44:269-78.

21. Indian Pharmacopeias. Vol. 2. Appendix 11.2, A-135; 1996. Available from: http://www.who.int/medicines/publications/ pharmacopoeia/WHOPSMQSM2006_2_IndexPharmacopoeiasU pdated.pdf. [Last accessed on 20 Dec 2018]

22. Vats A, Sharma P. Formulation and evaluation of topical antiacne formulation of coriander oil. Int J Pharm Pharm Sci Res 2012;2:61-6

23. Charde YM, Sharma PH, Choudhary NG, Avari JG. Development and evaluation of herbal formulation for the treatment of acne. Int J Pharm Sci Res 2014;5:2250-60.

24. Rajalakshmi SV, Vinay OG. Formulation development, evaluation, and optimization of medicated lip rouge containing niosomal acyclovir for the management of recurrent herpes labialis. Int J Appl Pharm 2017;9:21-17.

25. Wood JH, Catacalos G, Liberman SV. Adaptation of commercial viscometer for special application in pharmaceutical rheologyII. J Pharm Sci 1963;52:375-8.

26. Bauer AW, Kirby WM, Sherris JC, Truck M. Antibiotic susceptibility testing by a standardized single disc method. Am J Clinpathol 1966;45:493-6.

27. Ahmed A, Rowshan A, Sengupta R. Formulation and in vitro/ex vivo characterization of microemulsion based hydrogel formulation of aceclofenac for topical application. Asian J Pharm Clin Res 2016;9:87-91. 